\title{
ASPEK BIOLOGI DAN ABLASI MATA PADA UDANG WINDU Penaeus monodon SUKU PENAEIDAE (DECAPODA: MALACOSTRACA)
}

\author{
Oleh \\ Rianta Pratiwi ${ }^{1)}$
}

\begin{abstract}
THE ASPECTS OF BIOLOGY ANDEYE ABLATION ON SHRIMP Penaeus monodon PENAEIDAE (DECAPODA: MALACOSTRACA). A qood quality of seeds (fry) is a very important production component to support the shrimp farming activities in ponds. The quantity and quality of shrimp seeds are largely determined by hatchery products obtained from the quality of the broodstock used. The provision of the broodstock is the beginning of the seed production activities and is one of the factors that determines the quality and quantity of the production. The growing demand for mature gonad shrimp is a big problem for shrimp farmers, due to the ability of windu shrimp to spawn in the nature (ripe gonad naturally) takes relatively long time. Therefore, the eye ablation process can accelerate the process of gonad maturity. This article describes some aspects that should be understood in conducting windu shrimp farming as well as explanations of ablation process.
\end{abstract}

\section{PENDAHULUAN}

Keragaman jenis udang pada perairan laut di seluruh dunia diperkirakan dari famili Penaidae adalah berjumlah sekitar 318 spesies, dan sekitar 80 jenis diantaranya hingga saat ini belum dimanfaatkan. Dari jumlah tersebut, spesies udang dari genus Penaeus merupakan jenis udang terpenting, karena memiliki ukuran yang cukup besar. Dua diantaranya adalah udang windu (Penaeus monodon) dan udang putih (Penaeus merguiensis). Udang $P$. monodon atau yang selanjutnya disebut udang windu dalam tulisan ini, dikenal juga dengan sebutan black tiger shrimp. Jenis ini adalah jenis udang laut yang dapat mencapai ukuran besar, yang dapat mencapai panjang 35 centimeter

1) Pusat Penelitian Oseanografi-LIPI dan berat sekitar 260 gram. Sedangkan udang windu yang dibudidayakan di dalam tambak, panjang tubuhnya hanya mencapai 20 centimeter dengan berat tubuh sekitar 140 gram (Soetomo, 2000).

Udang windu merupakan udang asli dari perairan Indonesia. Jenis udang tersebut sangat digemari di seluruh dunia dan memiliki nilai ekonomis yang cukup tinggi, bahkan menjadi komoditas primadona dari Indonesia. Disamping itu, udang tersebut juga sangat penting bagi sektor perikanan, karena mempunyai nilai gizi yang tinggi, sehingga dapat dijadikan sebagai komoditas ekspor dan sumber devisa, serta memiliki nilai protein tinggi penunjang konsumsi masyarakat Indonesia maupun mancanegara. Berbagai upaya telah dilakukan dalam 
meningkatkan produksi udang windu, salah satu diantaranya adalah penerapan sistem budidaya udang windu secara intensif, yang dimulai sejak pertengahan tahun 1986 (Prasetyo, 2017).

Sejak tahun 1995 produksi jenis udang mengalami penurunan yang sangat drastis, hal ini karena adanya serangan penyakit pada areal pertambakan dan panti pembenihan (Tampangallo et al., 2012). Beberapa virus jenis Vibrio menjadi penyebab penyakit pada udang yang dikenal sebagai Vibriosis. yang menyerang larva udang, sehingga industri udang Indonesia mengalami masa pasang surut, terutama setelah merebaknya serangan virus Vibrio atau White Spot yang menghancurkan usaha budidaya udang di sebagian besar wilayah Indonesia, terutama pantai utara Jawa (Pantura). Namun demikian, karena permintaan udang yang semakin meningkat, maka pemerintah mendorong industri budidaya udang untuk lebih meningkatkan produksinya, sehingga di tahun 2012 mulai meningkat kembali dengan nilai produksi menjadi sebesar 300.000 ton atau dua kali lipat dari tahun-tahun sebelumnya. Komoditas udang diharapkan tetap menjadi primadona ekspor, dan Indonesia masih menempatkan udang $P$. monodon sebagai komoditas unggulan perikanan budidaya selama 2012-2014 (Prasetyo, 2017).

Penangkapan udang laut di beberapa lokasi telah berjalan dengan sangat intensifhingga telah mencapai atau melebihi produksi lestari (sustainable yield), misalnya di beberapa tempat pantai utara Jawa, pesisir Kalimantan, Sumatra dan Irian Jaya. Peningkatan produksi yang sangat tinggi dalam upaya memenuhi permintaan pasar ekspor, berdampak kepada meningkatnya permintaan benih udang, sehingga produksi benih udang harus dilakukan secara intensif. Salah satu cara untuk meningkatkan produksi benih udang adalah dengan melakukan ablasi yaitu proses mempercepat kematangan gonad. Permasalahan yang utama adalah udang windu memiliki kemampuan untuk matang gonad secara alami yang sangat lama (Prasetyo, 2017).

Pengetahuan dasar mengenai proses ablasi pada udang windu sangat penting diketahui, karena diperlukan untuk mempercepat proses kematangan gonad yang berhubungan dengan produksi benih udang tersebut. Spesimen yang digunakan dalam tulisan adalah dari referensi koleksi yang dimiliki oleh Pusat Penelitian Oseanografi-LIPI yang berasal dari perairan Indonesia. Tujuan dari tulisan ini adalah memberikan gambaran tentang aspek biologi udang windu yang sangat banyak dibudidayakan di perairan Indonesia dan pentingnya proses ablasi yang berpengaruh besar terhadap produksi benih udang windu $(P$. monodon).

\section{CIRI-CIRI UDANG WINDU (P. monodon)}

Jenis udang $P$. monodon atau lebih dikenal dengan nama lokal yaitu udang windu atau udang pacet. Ciriciri dari udang tersebut adalah pada bagian kepala dilindungi oleh karapas (cangkang kepala), dengan rostrum yang 
tajam melengkung. Pada rostrum bagian atas terdapat 7 atau 8 gerigi dan bagian bawah 2 atau 3 gerigi, biasa dituliskan dengan rumus 7-8/2-3. Rostrum melebihi ujung tangkai antennula, berbentuk kurva. Rostral karina hampir mencapai epigastrik dan postrostral karina hampir mencapai ujung belakang karapas. Bagian kepala lainnya adalah terdapatnya hepatik karina yang sangat jelas di bagian depan secara horizontal dan hepatik sulcus yang tidak begitu jelas terlihat. Di bagian mata juga terdapat sepasang mata majemuk (mata facet) bertangkai yang dapat digerakkan. Mulut terletak di bagian bawah kepala dengan rahang (mandibula) yang kuat. Sepasang antena juga terletak di bagian kepala dengan dua pasang antennula, serta sepasang maxilliped. Bagian badan (abdomen), terdiri dari 6 segmen yang satu dengan lainnya dihubungkan dengan selaput tipis. Terdapat 5 pasang kaki renang (pleopod) yang melekat pada segmen pertama sampai segmen ke lima. Segmen ke enam adalah bagian ekor (telson), berbentuk kipas (uropod) dan diantaranya terdapat bagian yang runcing, yang disebut dengan telson (Gambar 1). Tubuh udang windu dibentuk oleh dua cabang (biramous), yaitu exopodite dan endopodite. Aktifitas berganti kulit luar atau eksoskleton secara perodik biasa disebut dengan istilah moulting (Mujiman \& Suyanto, 2003; Pratiwi, 2008).

Udang windu juga memiliki ciriciri kulit tubuh yang keras, berwarna hijau kebiru-biruan dan bercorak lorengloreng besar. Udang windu yang sudah dewasa dan hidup di laut, memiliki ciriciri warna kulit merah muda kekuningkuningan dengan ujung kaki renang yang berwarna merah, sedangkan udang windu yang masih muda memiliki ciri khas berwarna merah muda dengan bintikbintik hijau (Kordi, 2010).

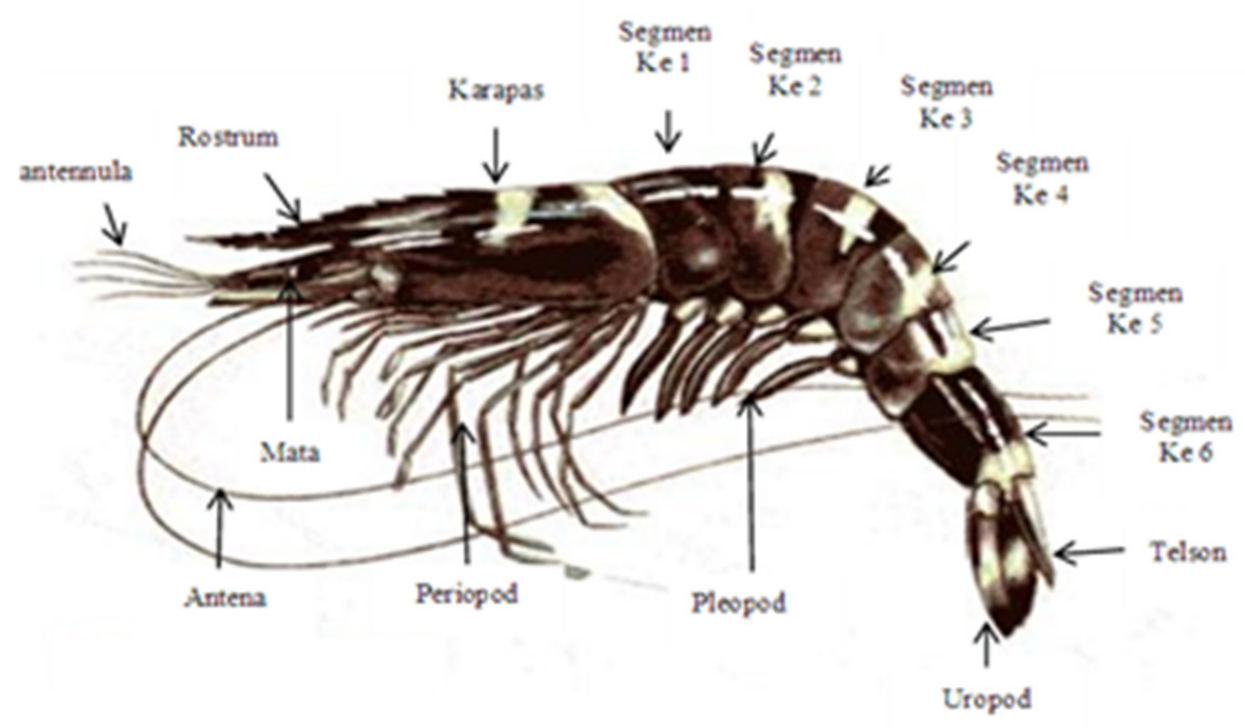

Gambar 1. Udang windu (P. monodon) (Suwignyo, 1990). 
Induk yang digunakan untuk budidaya diperoleh dari alam, yang diperkirakan telah melakukan pemijahan di alam. Udang windu yang pada bagian abdomennya berwarna kemerah-merahan menunjukan bahwa udang tersebut berasal pada daerah yang dalam (pada laut dalam), sedangkan induk yang pada bagian abdomennya berwarna kehitamhitaman menunjukan bahwa udang tersebut berasal dari daerah yang dangkal (Prasetyo, 2017).

\section{PERBEDAAN JANTAN BETINA}

Alat reproduksi antara udang jantan dan udang betina terdapat perbedaan yang khas. Cara untuk membedakan udang jantan dan udang betina, dapat dilihat dari alat kelaminnya yang secara morfologi terlihat sangat jelas. Alat kelamin jantan udang disebut dengan petasma, yang terletak pada kaki renang pertama, sedangkan lubang saluran kelaminnya disebut dengan gonophore terletak diantara pangkal kaki jalan ketiga. Alat kelamin udang betina disebut dengan thelycum, terletak diantara kaki jalan ke empat dan ke lima (Pratiwi, 2008). Menurut Lestari (2009), sistem reproduksi betina menggunakan sepasang ovarium, oviduk, lubang genital dan thelycum, sedangkan sistem reproduksi jantan menggunakan testes, vasa deferensia, petasma dan apendiks maskulina. Alat kelamin udang dapat dilihat pada Gambar 2.

Pada udang jantan dewasa, gonad akan menjadi testis yang berfungsi sebagai penghasil mani (sperma). Pada udang betina, gonad akan menjadi indung telur (ovarium), yang berfungsi menghasikan telur. Ovarium yang telah matang akan menghasilkan telur dalam jumlah yang banyak. Telur-telur akan merekat pada ovarium dan terangkai seperti buah anggur yang meluas sampai ekor. Sperma yang dihasilkan oleh udang jantan, pada saat kawin akan dikeluarkan dalam kantung seperti lendir yang disebut dengan kantung sperma (spermatophore). Spermatophore dilekatkan pada thelycum udang betina dan disimpan terus disana hingga saat peneluran dengan bantuan petasma. Apabila udang betina bertelur, spermatophore akan pecah, dan selsel sperma akan membuahi telur di luar badan induknya (Mujiman \& Suyanto, 2003; Pratiwi, 2008).
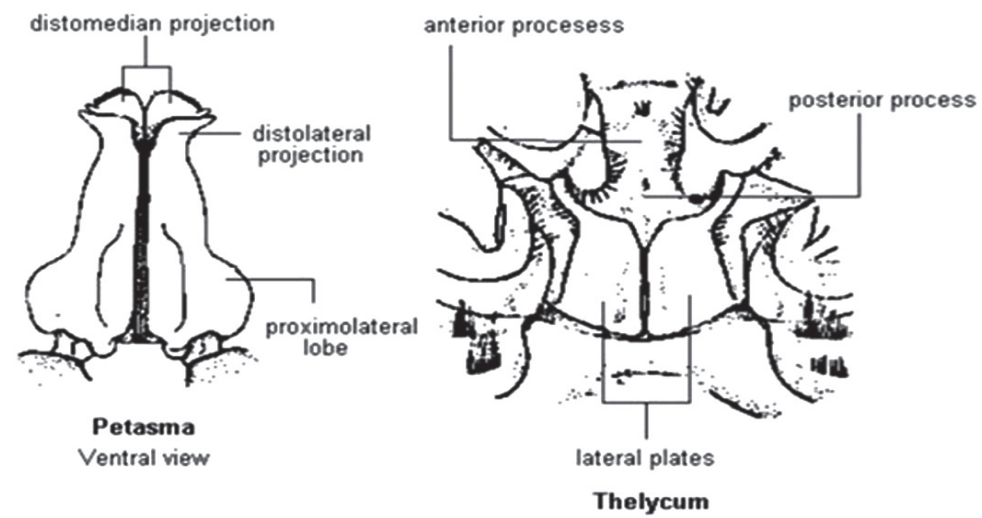

Gambar 2. Alat kelamin udang Windu jantan (Petasma) dan alat kelamin udang Windu betina (Thelycum) (Paula, 1988. http://www.india ocean.org.). 


\section{TINGKAH LAKU UDANG WINDU}

Umumnya udang dan semua bangsa krustasea bersifat kanibal, yaitu memangsa sesama jenis yang lebih lemah kondisinya misalnya udang yang sedang dalam proses ganti kulit seringkali dimakan oleh udang lain. Udang berukuran lebih kecil dimakan oleh udang besar terutama bila dalam keadaan kurang makan. Hidup di dasar perairan, tidak menyukai cahaya terang dan bersembunyi di lumpur pada siang hari, bersifat kanibal terutama dalam keadaan lapar dan tidak ada makanan yang tersedia, mempunyai ekskresi amonia yang cukup tinggi dan untuk pertumbuhan diperlukan pergantian kulit (moulting). Pertumbuhan udang yang sangat cepat dan menyerap air lebih banyak sampai kulit luar yang baru mengeras yaitu pada saat proses pergantian kulit. Pergantian kulit merupakan indikator dari pertumbuhan udang, semakin cepat udang berganti kulit berarti pertumbuhan semakin cepat pula. Udang berganti kulit secara periodik, dan pada proses ganti kulit tersebut badan udang berkesempatan untuk bertumbuh besar secara nyata. Udang muda lebih sering ganti kulit daripada udang tua, sehingga udang muda lebih cepat tumbuh dibandingkan dengan yang lebih tua. Semua udang memiliki sifat alami yang sama, yakni aktif pada malam hari (nocturnal), baik aktifitas untuk mencari makan dan reproduksi (Sumeru \& Umiyati, 1992).

Beberapa indera yang digunakan udang untuk mendeteksi makanan adalah penglihatan(sight), audiosense, thermosense dan chemosense. Indera keempat yaitu chemosense atau chemoreseptor merupakan alat yang paling peka untuk mendeteksi pakan. Dalam mencari pakan udang lebih mengandalkan indera perasa seperti antenna flagella, rongga mulut, kaki jalan, carapace daripada indera penglihatan (Sumeru \& Umiyati, 1992). Hal ini diperkuat oleh pendapat Ache (1982), yang menyatakan bahwa alat chemoreseptor pada krustase bersifat sensitif dalam memberikan respon untuk bahan-bahan kimia, sebaik respon terhadap temperatur dan $\mathrm{pH}$.

Udang windu memiliki daya tahan yang sangat kuat terhadap salinitas, dan suhu. Pada waktu masih benih, udang bersifat euryhaline yang sangat tahan terhadap fluktuasi kadar garam oleh sebab itu udang windu dapat dipelihara di tambak dengan kadar garam bervariasi mulai dari kisaran salinitas 3-5 \% pada tambak yang jauh dari laut, hingga tambak yang dekat dengan laut yang salinitas berkisar 20-30 $\%$. Pada tambak yang berair dangkal, daya tahan udang windu terhadap perubahan suhu juga cukup besar. Pada malam hari suhu dapat mencapai $22^{\circ} \mathrm{C}$ atau di bawah $25^{\circ} \mathrm{C}$, namun di siang pada hari terutama pada musim kemarau suhu sering mencapai $31{ }^{\circ} \mathrm{C}$. Meskipun demikian udang windu tetap dapat tumbuh dengan cukup baik (Suyanto \&Takarina, 2009).

\section{SIKLUS HIDUP DAN REPRODUKSI UDANG WINDU}

Layaknya biota yang lain, udang windu juga memiliki daur hidup atau fase-fase yang harus dilalui selama hidupnya. Daur hidup udang meliputi beberapa tahapan yang membutuhkan habitat yang berbeda pada setiap tahapan. Awalnya, udang windu muda akan menyukai daerah-daerah dangkal, 
seperti muara air payau yang salinitasnya rendah. Seiring dengan berjalannya usia, udang akan pindah ke habitat yang lebih dalam, lebih tenang, dan lebih jernih untuk membantu proses pertumbuhannya. Udang melakukan pemijahan di perairan yang relatif dalam. Setelah menetas, larvanya yang bersifat planktonis terapung-apung dibawa oleh arus, kemudian berenang mencari air dengan salinitas rendah di sekitar pantai atau muara sungai. Di kawasan pantai, larva udang tersebut berkembang. Menjelang dewasa, udang tersebut beruaya kembali ke perairan yang lebih dalam dan memiliki tingkat salinitas yang lebih tinggi untuk kemudian memijah. Tahapan-tahapan tersebut berulang untuk membentuk siklus hidup. Udang dalam pertumbuhan dan perkembangannya mengalami beberapa fase, yaitu nauplius, zoea, mysis, postlarva, juvenil (udang muda), dan udang dewasa (Fast \& Laster, 1992).

Setelah telur-telur menetas, larva hidup di laut lepas menjadi bagian dari zooplankton. Saat stadium postlarva bergerak ke daerah dekat pantai dan perlahan-lahan turun ke dasar di daerah estuari dangkal. Perairan dangkal ini memiliki kandungan nutrisi, salinitas dan suhu yang sangat bervariasi dibandingkan dengan laut lepas. Setelah beberapa bulan hidup di daerah estuari, udang dewasa kembali ke lingkungan laut dalam, dimana kematangan sel kelamin, perkawinan dan pemijahan terjadi. Udang windu akan mencapai kematangan secara seksual pada usia 1,5 tahun. Setelah mencapai fase tersebut, udang akan melakukan perkawinan dan kemudian menghasilkan keturunan yang baru. Umumnya, perkawinan udang windu terjadi pada waktu malam, lebih sering lagi ketika sedang bulan purnama (Effendi, 2002).

Siklus hidup udang windu sebenarnya telah banyak diteliti antara lain oleh Motoh $(1981 ; 1985)$ yang membagi daur hidup udang windu menjadi enam tahap, yaitu sebagai berikut:

a. Tahap embrio. Dimulai pada saat pembuahan sampai penetasan;

b. Tahap larva. Pada tahap ini terdiri dari stadium naplius, zoea, mysis, dan postlarva. Akhir dari tahap ini, ditandai bahwa pada ruas abdomen keenam yang lebih panjang dari panjang cangkang dan warna tubuh yang transparan ditutupi oleh pita berwarna coklat gelap memanjang dari pangkal antena hingga telson;

c. Tahap juvenil. Pada stadium awal ditandai oleh warna tubuh yang transparan dengan pita cokelat gelap di bagian sentral. Tahap ini ditandai dengan fluktuasi perbandingan ukuran tubuh mulai stabil, yang berarti telah menginjak tahap udang muda;

d. Tahap udang muda. Pada tahap ini proporsi ukuran tubuh mulai stabil dan tumbuh tanda-tanda seksual, dimana alat kelamin pada udang windu jantan yaitu petasma mulai terlihat setelah panjang cangkangnya $30 \mathrm{~mm}$, sedangkan pada betina thelycum mulai terlihat setelah panjang cangkang mencapai $37 \mathrm{~mm}$; 
e. Tahap sub adult. Ditandai dengan adanya kematangan seksual;

f. Tahap dewasa. Udang windu dewasa ditandai dengan kematangan gonad yang sempurna. Pada udang jantan mempunyai spermatozoa pada pasangan ampula terminalis dan pada udang betina mempunyai ovocytus yang telah berkembang di dalam ovariumnya.

Pada stadium postlarva, anakan udang windu hidup merayap atau melekat pada benda-benda dasar perairan. Di muara-muara sungai, terlebih di perairan sekitar hutan mangrove, anakan udang ini banyak ditemukun. Anakan udang ini hidup di daerah tersebut dengan menyesuaikan diri pada salinitas yang bervariasi antara 4-35\%. Udang muda ini akan segera kembali lagi ke laut untuk tumbuh menjadi besar, dewasa dan akhirnya memijah. Dari menetas sampai mencapai stadium post larva diperlukan waktu sebulan, dari post larva sampai ke juwana sekitar 3-4 bulan, sedangkan dari juwana hingga mencapai dewasa diperlukan waktu selama delapan bulan. Makanan udang pada stadium larva adalah alga renik (microalgae), terutama diatomae dan berbagai jenis zooplankton. Udang dikenal bersifat omnivor yang memakan bukan saja tumbuhan dan hewan kecil, tetapi juga detritus (Mujiman \& Suyanto, 2003).

Kira-kira 12 jam setelah dikeluarkan, telur menetas menjadi larva yang pada stadium pertama disebut nauplius. Setelah mengalami pergantian kulit beberapa kali, nauplius kemudian menjadi zoea. Pada stadium zoea, larva mulai mengambil makanan dari sekitarnya. Giliran selanjutnya, bentuk zoea akan berubah lagi menjadi mysis. Dari stadium mysis, larva bermetamorfose menjadi stadium postlarva. Anakan udang yang bersifat planktonik ini kemudian berupaya migrasi ke pantai, cenderung ke perairan muara sungai (Mujiman \& Suyanto, 2003).

Ketersedian induk udang dengan kualitas baik, serta jumlah yang cukup sangat penting bagi usaha pembenihan udang. Dalam hal ini, pemilihan induk udang sangat menentukan keberhasilan pembenihan udang windu. Sebagai pedoman, kriteria induk udang windu yang baik serta produktif menurut Murtidjo (2003), adalah sebagai berikut:

1. Berat induk udang betina minimal $100 \mathrm{~g}$, sedangkan induk udang jantan minimal 80 gram;

2. Tubuh induk udang tidak cacat luka, terutama organ reproduksi dan bagian punggung;

3. Bentuk punggung induk udang relatif datar dan berkulit keras.

Perkembangan gonad merupakan bagian darireproduksiikan sebelumterjadi pemijahan. Menurut Effendi (2002), pengamatan kematangan gonad dapat dilakukan dengan dua cara, yaitu cara histologi dan morfologi di laboratorium maupun di lapangan. Penelitian yang dilakukan secara histologi akan diketahui anatomi perkembangan gonad tadi lebih jelas dan mendetil, sedangkan hasil pengamatan secara morfologi tidak akan 
sedetil dengan cara histologi, namun cara morfologi ini banyak dilakukan para peneliti.

Tingkat kematangan gonad pada induk udang betina dapat dirangsang supaya udang cepat melakukan pemijahan. Menurut Murtidjo (2003), bahwa ada beberapa cara yang dapat dilakukan, antara lain:

1. Pemijatan tangkai bola mata dan bola mata;

2. Pembakaran tangkai mata dengan menggunakan solder atau dengan benda perak nitrat;

3. Pengikatan tangkai mata;

4. Pemotongan atau pengguntingan tangkai mata.

Cara yang paling praktis dan efektif, serta menunjukkan hasil yang baik adalah dengan melakukan pemotongan tangkai mata (ablasi). Ablasi pada udang windu berpedoman pada perkembangan alat kelamin kepiting yang dihambat oleh hormon yang dikeluarkan oleh kelenjar pada tangkai mata. Apabila tangkai mata kepiting dihilangkan, hormon yang menghambat perkembangan alat kelamin tidak diproduksi, sehingga kepiting sanggup mematangkan telur dan memijah (Hadie et.al., 1995; Yusuf, 2011; Anam et.al., 2016).

\section{APA ITU ABLASI?}

Pemijahan induk udang windu di Indonesia selama ini memakai teknik konvensional. Salah satu masalah utama pada pembenihan undang windu adalah kemampuan induk untuk matang gonad secara alami yang sangat lama di alam. Kematangan gonad induk udang hanya dapat dicapai dengan ablasi tangkai mata. Ablasi mata adalah usaha untuk mempercepat kematangan gonad dengan cara merusak sistem saraf tertentu yang terdapat dalam tubuh udang. Bagian tubuh udang yang dirusak adalah bagian mata, sebab pada tubuh udang, mata selain berfungsi sebagai alat penglihatan juga merupakan tempat saraf yang diantaranya sangat berpengaruh dalam proses perkembangbiakan (Amien \& Iromo, 2014).

Definisi lain tentang ablasi adalah proses pemotongan tangkai mata udang yang terdapat organ $\mathrm{X}$ sebagai penghasil hormon perkembangan dan pematangan gonad (Gonade Inhibiting Hormonel GIH), serta penghambat pergantian kulit (Moulting Inhibiting Hormonel $\mathrm{MIH}$ ). Jika organ $\mathrm{X}$ sudah tidak ada, maka organ $\mathrm{Y}$ yang terletak di kepala dapat menghasilkan hormon perangsang pembentukan gonad (Gonad Stimulating Hormone/GSH), sehingga proses pematangan gonad dapat berlangsung cepat (Hadie et. al., 1995). Untuk lebih jelasnya proses tersebut dijelaskan dengan alur pada Gambar 3. 


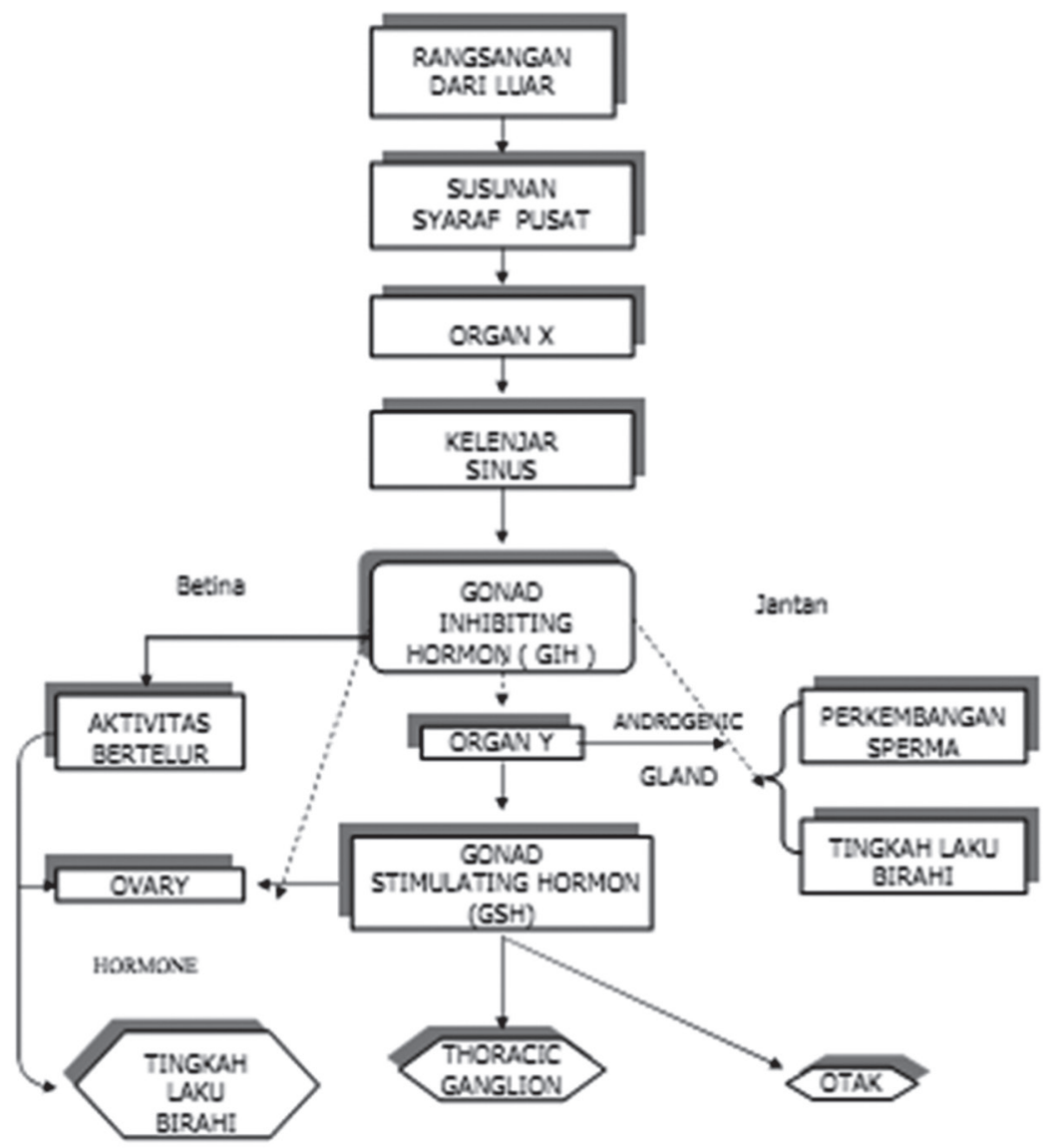

Gambar 3. Sistem hormon pada udang Windu (Setiawan, 2004).

Keterangan: Garis $=$ Berpengaruh tidak langsung Garis $=$ Berpengaruh langsung

Proses ablasi menurut Suyanto \& Takarina, 2009; Prasetyo, 2017 adalah sebagai berikut:

1. Akibat adanya rangsangan dari luar, susunan saraf pusat memerintahkan $\mathrm{X}$ organ, untuk menghasilkan Gonad Inhabiting Hormon (GIH);

2. GIH disimpan di dalam sinus gland yang terletak pada tangkai mata;

3. GIH berfungsi menghambat perkembangan androgenic gland pada individu jantan dan ovarium pada individu betina;

4. GIH menghambat kegiatan $\mathrm{Y}$ organ pada bagian kepala;

5. Y organ penghasil Gonad Stimulating Hormone (GSH) yang berfungsi merangsang pembentukan sperma dan telur;

6. Agar perkembangan telur pada 
induk betina lebih baik, maka perkembangan GIH diputus.

Meskipun metode ini sangat mudah, namun ablasi dapat menyebabkan gangguan metabolisme asam lemak, perilaku renang udang menjadi miring, penurunan kualitas gamet, stres dan kematian apabila salah langkah. Proses ablasi mata harus dilakukan dengan hati-hati agar tidak merusak jaringan atau organ lain dari induk udang. Tujuan teknik ablasi adalah untuk mengurangi atau menghilangkan kerja organ-X, yang memproduksi hormon penghambat kematangan gonad atau GIH dan MIH. Turunnya kerja organ-X akan meningkatkan kerja organ-Y yang menghasilkan hormon GSH atau hormon untuk mempercepat kematangan gonad dan MH (molting hormone) (Yusuf, 2011).

Beberapa teknik untuk melakukan proses ablasi dan menurut Amin \& Iromo (2014); Suyanto \& Takarina. (2009) adalah sebagai berikut :

1. Pincing, yaitu menjepit salah satu tangkai mata udang tanpa pemanasan dan tidak sampai putus;

2. Ligation, yaitu menjepit salah satu tangkai mata udang dengan pemanasan dan tidak sampai putus;

3. Cauttery, yaitu memencet tangkai mata udang sampai putus;
4. Cutting, yaitu memotong tangkai mata udang dengan gunting (Gambar 4).

Adapun tahapan-tahapan dalam melakukan proses ablasi menurut Suyanto \& Takarina (2009) adalah sebagai berikut:

1. Siapkan alat berupa gunting yang steril;

2. Induk udang yang akan diablasi, ditangkap dengan seser dan dipilih induk yang memiliki kulit keras;

3. Induk direndam dengan malachite green 25 ppm sekitar 2-3 menit, kemudian dimasukan ke dalam larutan antibiotik yaitu oxytetracycline sebanyak 25 ppm;

4. Induk dilengkungkan badannya dengan cara meletakkan ibu jari di atas karapas dan jari kelingking harus menekan ekor udang;

5. Potong salah satu tangkai mata udang dengan gunting yang steril sampai putus;

6. Induk yang dipotong masukan dalam bak perkawinan dan dicampur dengan induk jantan untuk melakukan perkawinan;

7. Perbandingan jantan dan betina $1: 2$ atau 2:3 tergantung jumlah induk dan kebutuhan. 


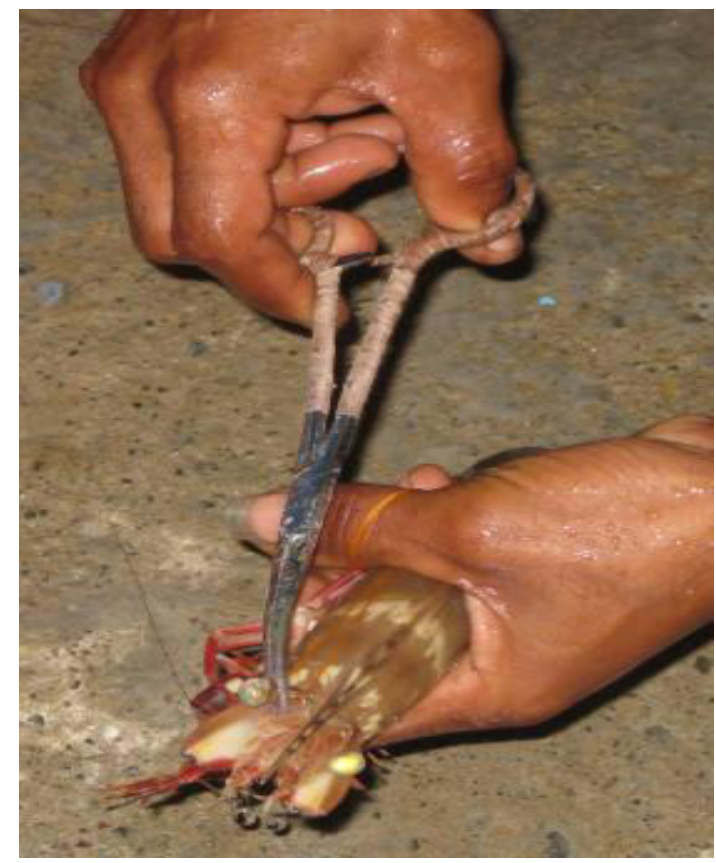

Gambar 4. Salah satu tahapan proses ablasi mata, yaitu memotong tangkai mata dengan menggunakan gunting (Anonim, 2018).

Ablasi mata dilakukan pada udang yang belum matang gonad, hal ini dimaksudkan untuk merangsang penetasan telur. Fungsi larutan oxytetracycline tersebut untuk menghindari terjadinya infeksi pada mata udang yang telah diablasi, serta menghilangkan ektoparasit yang ada pada tubuh udang. Fungsi ablasi pada mata udang yaitu untuk menghilangkan hormon $\mathrm{x}$ yang dapat menghambat pematangan gonad (Yusuf, 2011).

Menurut beberapa peneliti budidaya dari Balai Penelitian dan Pengembangan Budidaya Air Payau (BPPBAP) Maros Sulawesi Selatan, dengan menghilangkan tangkai mata udang sangat efektif untuk proses kematangan gonad yang makin cepat.
"Teknik ini masih dipakai karena belum ada aplikasi lain yang bisa diadopsi unit perbenihan udang untuk memacu pematangan gonad". Kelemahan dari teknik ini dapat menyebabkan kerusakan permanen pada mata udang, menurunkan sintetis neurohormon secara signifikan, mengganggu sistem endokrin, serta proses fisiologis dalam tubuh udang. Selain itu "teknik inipun kurang memenuhi kaidah kesejahteraan hewan”. Ablasi mata juga menjadi isu terkait dengan animal welfare yang dapat menjadi kendala dalam perdagangan ekspor. Manipulasi reproduksi secara hormonal telah diketahui mampu mempercepat pematangan gonad (Yusuf, 2011; Prasetyo, 2017). 


\section{PENUTUP}

Udang windu ( $P$. monodon) merupakan salah satu jenis udang asli dari perairan Indonesia yang sangat digemari di seluruh dunia dan memiliki nilai ekonomis yang tinggi, bahkan menjadi komoditas primadona dari Indonesia. Selain itu udang tersebut juga sangat penting bagi sektor perikanan, karena mempunyai nilai gizi yang tinggi, sehingga dapat dijadikan sebagai komoditas ekspor dan sumber devisa serta memiliki nilai protein tinggi penunjang konsumsi masyarakat Indonesia maupun mancanegara. Keistimewaan yang dimiliki oleh udang tersebut sangat disayangkan tidak dibarengi oleh kemampuannya untuk berpijah di alam secara cepat (matang gonad secara alami), oleh karena harus dibantu dengan cara dibudidayakan dan dilakukan proses ablasi mata.

Dikarenakan udang windu sangat lama melakukan pemijahan di alam, maka untuk mempecepat proses tersebut dapat dilakukan dengan cara proses ablasi mata di laboratorium. Adapun caranya adalah dengan merusak sistem saraf tertentu yang terdapat dalam tubuh udang. Bagian tubuh udang yang dirusak adalah bagian mata, sebab mata, selain berfungsi sebagai alat penglihatan juga merupakan tempat saraf yang diantaranya sangat berpengaruh dalam proses perkembangbiakan. Proses tersebut harus dilakukan dengan hati-hati agar tidak merusak jaringan atau organ lain dari induk udang. Metode ini sangat mudah dilakukan, tetapi harus berhatihati dalam melakukannya, karena dapat menyebabkan gangguan metabolisme asam lemak, perilaku renang udang menjadi miring, penurunan kualitas gamet, stres dan bahkan kematian. Pengetahuan mengenai aspek biologi dari udang windu sangat diperlukan dan dipahami apabila akan melakukan kegiatan budidaya, karena udang dari suku Penaeidae ini mempunyai karakter dan ciri-ciri tersendiri baik dalam tingkah laku, reproduksi dan siklus hidupnya.

\section{DAFTAR PUSTAKA}

Ache, B. W. 1982. Chemoreception and thermoreception in the biology of crustacea. Academic Press New York, 369-393.

Anam, C., A. Khumaidi dan A. Muqsith. 2016. Manajemen produksi naupli udang Vaname (Litopenaeus vanname) di instalasi pembenihan udang (IPU) Gelung Balai Perikanan Budidaya Air Payau (BPBAP) Situbondo Jawa Timur. Jurnal Ilmu Perikanan, 7 (2): 57-65.

Anonim, https://www.google.com/searc $\mathrm{h} ? \mathrm{q}=$ proses + ablasi + mata + pad $\mathrm{a}+$ udang + windu\&client $=$ firef ox-\&source $=1 \mathrm{nms} \&$ tbm $=$ isch $\&$ $\mathrm{sa}=\mathrm{X} \& \mathrm{ved}=0 \mathrm{ahUKEwjpmLS}$ 1jvaAhUjTo8KHUQXDIEQ AUICigB\&biw $=1207 \& b i h=555$ (diakses pada tanggal 4 Mei, 2018).

Amien, M. H., dan H. Iromo. 2014. Optimalisasi reproduksi induk untuk menjaga keseimbangan 
populasi udang windu di perairan Tarakan, Kalimantan Utara. Jurnal Harpodon Borneo, 7 (2): 102-108.

Bunga, R. Tampangallo., C. S. Pakidi dan A. Rantetondok. 2012. Respon Imun Udang Windu (Penaeus monodon) yang Dipapar Bakteri Vibrio harveyi. Pros. InSiNas: 265-269.

Effendi, I. 2002. Biologi Perikanan.

Yayasan Pustaka Nusantara, Yogyakarta. 57 Hal.

Fast, A. W., and L. J. Lester. 1992. Marine Shrimp Culture: Principles and Practices. Development in Aquaculture and Fisheries Science, 23. 102 pp.

Hadie, W., S. Rejeki dan L. E. Hadie. 1995. Pengaruh pemotongan tangkai mata (Ablasi) terhadap pertumbuhan juvenile udang Galah (Macrobrachium rosenbergii). Jurnal Penelitian Perikanan Indonesia, 1 (1): $37-$ 44.

Kordi, K. 2010. Budidaya udang laut. Penerbit Andi. Yogyakarta, 80. Hal.

Lestari, A. 2009. Manajemen resiko dalam usaha pembenihan udang Vannamei (Litopenaeus vannamei), Studi kasus di PT. Suri Tani Pemuka, Kabupaten Serang, Provinsi Banten. Departemen Agribisnis, Fakulatas Ekonomi dan Manajemen, Institut Pertanian
Bogor. [Skripsi], 89 hal.

Murtidjo, B. A. 2003. Benih Udang Windu Skala Kecil. Kansius. Jakarta, 25 hal

Motoh, H. 1979. Larvae of decapod Crustacea of the Philippines - III Larval development of the giant tiger prawn, Penaeus monodon reared in the laboratory. Bulletin of the Japanese Society of Scientific Fisheries, 45(10): 1201-1216.

Motoh, H. 1981. Study on fisheries biology of the giant tiger prawn Penaeus monodon in the Philippines. SEAFDEAC. Tehnical Report No. 7. 128 pp.

Motoh, H. 1985. Biology and ecology of Penaeus monodon in Taki Y, Primavera J. H, Llobrera J. A. (eds), Proceedings of the First International Conference on the Culture of Penaeid Prawns/Shrimps, Iliolo City, Philippines. Aquaculture Department, Southeast Asian Fisheries Development Center, pp 27-36.

Mujiman, A. dan R. Suyanto. 2003. Budidaya Udang Windu. Penebar Swadaya. Jakarta. 211 hal.

Paula, D. 1998. National institute of oceanography images. Bioinformatic centre India. Goa. http://www.india_ocean. org. Tanggal akses 28 April 2018, 5 pp. 
Prasetyo, D. 2017. Performa reproduksi udang windu Penaeus monodon pasca injeksi hormon PMSG dan antidopamin Sekolah Pasca Sarjana Institut Pertanian Bogor. [Skripsi]. 40 hal.

Pratiwi, R. 2008. Aspek biologi udang ekonomis penting. Oseana, 33 (2): $15-24$.

Setiawan, A. 2004. Modul pemijahan induk udang. Direktorat Pendidikan Menengah Kejuruan. Direktorat Jenderal Pendidikan Dasar dan Menengah Departemen Pendidikan Nasional. 32 hal.

Sumeru, A. S. dan S. Umiyati, 1992. Pakan udang windu (Penaeus monodon). Kanisius, Yogyakarta. 94 Hal.

Soetomo, M. J. A. 2000. Tehnik budidaya udang windu (P. monodon). Kanisius, Yogyakarta. 78 Hal.
Suyanto, R., dan E. P. Takarina, 2009. Panduan Budidaya Udang Windu. Penebar Swadaya. 56 hal

Suwignyo, S. 1990. Avertebrata air. Lembaga Sumber Daya Informasi, Insititut Pertanian Bogor. 36 hal.

Tampangallo, B. R., C. S. Pakidi dan A. Rantetondok. 2012. Respon imun udang windu (Penaeus monodon) yang dipapar bakteri Vibrio harveyi. Prosiding InSiNas, 265-269.

Yusuf, K. 2011. Effektivitas dan efisiensi antidopamin dan hormon GTH sebagai pengganti ablasi mata dalam upaya percepatan kematangan gonad udang Vaname. Departemen Budidaya Perairan Fakultas Perikanan dan Ilmu Kelautan, Institut Pertanian Bogor. [Skripsi], 37 hal. 